HEALTH AND WORK 
Also by Lesley Doyal

What Makes Women Sick: Gender and the Political

Economy of Health 


\section{HeALTH AND WoRK}

\section{CRIticAl PeRsPectives}

edited by

Norma Daykin and Lesley Doyal

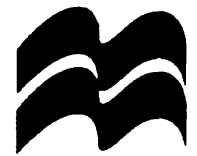


First published in Great Britain 1999 by

MACMILLAN PRESS LTD

Houndmills, Basingstoke, Hampshire RG21 6XS and London

Companies and representatives throughout the world

A catalogue record for this book is available from the British Library.

ISBN 978-0-333-69191-5 ISBN 978-1-349-27625-7 (eBook)

DOI 10.1007/978-1-349-27625-7

First published in the United States of America 1999 by

ST. MARTIN'S PRESS, INC.,

Scholarly and Reference Division,

175 Fifth Avenue, New York, N.Y. 10010

ISBN 978-0-312-22342-7

Library of Congress Cataloging-in-Publication Data

Health and work : critical perspectives / edited by Norma Daykin and

Lesley Doyal.

p. $\mathbf{c m}$.

Includes bibliographical references and index.

ISBN 978-0-312-22342-7 (cloth)

1. Industrial hygiene. I. Daykin, Norma. II. Doyal, Lesley.

RC967.H425 1999

$616.9 ' 803-\mathrm{dc} 21$

99-19219

CIP

Selection and editorial matter (C Norma Daykin and Lesley Doyal 1999

Introduction @ Norma Daykin 1999

Individual chapters (in order) (c) Lesley Doyal, Sarah Payne, Liz Lloyd, Graham Scambler

and Annette Scambler, Theo Nichols, Andrew Watterson, Karen Messing, Joyce E.

Canaan, Ruth Pinder, Tamsin Wilton, Nick J. Fox, Simon Pickvance, Rene Loewenson,

Asa C. Laurell and Christer Hogstedt 1999

Softcover reprint of the hardcover 1st edition 1999

All rights reserved. No reproduction, copy or transmission of this publication may be made without written permission.

No paragraph of this publication may be reproduced, copied or transmitted save with written permission or in accordance with the provisions of the Copyright, Designs and Patents Act 1988, or under the terms of any licence permitting limited copying issued by the Copyright Licensing Agency, 90 Tottenham Court Road, London W1P 9HE.

Any person who does any unauthorised act in relation to this publication may be liable to criminal prosecution and civil claims for damages.

The authors have asserted their rights to be identified as the authors of this work in accordance with the Copyright, Designs and Patents Act 1988.

This book is printed on paper suitable for recycling and made from fully managed and sustained forest sources.

$\begin{array}{llllllllll}10 & 9 & 8 & 7 & 6 & 5 & 4 & 3 & 2 & 1\end{array}$

$\begin{array}{llllllllll}08 & 07 & 06 & 05 & 04 & 03 & 02 & 01 & 00 & 99\end{array}$ 


\section{Contents}

Notes on Contributors vii

Preface $x i$

Acknowledgements xiii

Introduction: Critical Perspectives on Health and Work Norma Daykin

1 Women and Domestic Labour: Setting a Research Agenda

Lesley Doyal

2 Paid and Unpaid Work in Mental Health: Towards a New Perspective

Sarah Payne

3 The Wellbeing of Carers: An Occupational Health Concern

Liz Lloyd

4 Health and Work in the Sex Industry

Graham Scambler and Annette Scambler

5 Death and Injury at Work: A Sociological Approach 86 Theo Nichols

6 Why We Still Have 'Old' Epidemics and 'Endemics' in Occupational Health: Policy and Practice Failures and Some Possible Solutions

Andrew Watterson 
7 Tracking the Invisible: Scientific Indicators of the Health Hazards in Women's Work

Karen Messing

8 In the Hand or in the Head? Contextualising the Debate about Repetitive Strain Injury (RSI) Joyce E. Canaan

9 Zones of Danger, Zones of Safety: Disabled People's Negotiations around Sickness and the Sick Record 161 Ruth Pinder

10 Selling Sex, Giving Care: The Construction of AIDS as a Workplace Hazard

Tamsin Wilton

11 Postmodern Reflections: Deconstructing 'Risk', 'Health' and 'Work'

Nick J. Fox

12 Occupational Health Issues and Strategies: A View from Primary Health Care

Simon Pickvance

13 Participatory Approaches in Occupational Health Research

Rene Loewenson, Asa C. Laurell and

Christer Hogstedt

Index 


\section{NOTES ON CONTRIBUTORS}

Joyce E. Canaan is Senior Lecturer in the Sociology Department at the University of Central England. She has published numerous chapters in the area of the ethnography of education and has recently coedited (with Debbie Epstein) A Question of Discipline: Pedagogy and Power in the Teaching of Cultural Studies (Westview: Boulder, Colorado and Oxford, UK, 1997). She has also recently completed a study with Baljit Kaur Basatia and Surinder Kaur of the AEKTA Project in Birmingham, funded by the Barrol-Cadbury Foundation, entitled The Double Burden Intensified: Asian Women Homeworkers' Perceptions of their Pay and Conditions (1999).

Nick J. Fox is Senior Lecturer in sociology in the School of Health and Related Research (ScHARR) at the University of Sheffield. He is the author of The Social Meaning of Surgery (Open University Press, 1992) and Postmodernism, Sociology and Health (Open University Press, 1993). He has written extensively on postmodern social theory as applied to health and care and is currently completing a new book in this field entitled Beyond Health: Blueprint for a Postmodern Embodiment (Free Association Books, 1999).

Christer Hogstedt is Professor of Occupational Health at the Swedish National Institute for Working Life and directs NIWL's multidisciplinary Department for Work and Health. He is also senior physician at the Karolinska Hospital and at the Labour Inspectorate, both in Stockholm. He has served as expert advisor on environmental health to the Swedish Government's Ministry of Health and Social Welfare and as president of the Swedish Association for Occupational Health and Safety in Developing Countries. He has also served as consultant to several international bodies including the World Health Organisation and the International Commission on Occupational Health. He has edited 14 books (five international) and published over 200 scientific articles as well as numerous papers and contributions at international conferences. 
Asa C. Laurell is Professor of Social Medicine at the Autonomous Metropolitan University in Mexico City. Her professional training is in medicine and she has an MPH and a PhD in Sociology. She has published extensively on work process and health as well as health policy and social security reform. Her publications include the books La Salud en la Fabrica (Health in the Factory) and La Reforma contra la Salud y la Seguridad Social (The Reform against Health and Social Security). She has also served as a consultant to trade unions and to the Commissions of Health and Social Security of the Mexican Congress.

Liz Lloyd is a Lecturer in Community Care in the School for Policy Studies at the University of Bristol. She is the author of a number of journal articles and papers on health and social care services for elderly people. Her current research is on community care for elderly people through the process of dying.

Dr Rene Loewenson is a Zimbabwean epidemiologist. She has worked as a Senior Lecturer in the Department of Community Medicine at the University of Zimbabwe Medical School; as Head of the Zimbabwe Congress of Trade Unions Health and Social Welfare Department and as Technical Co-ordinator for the Organisation of African Trade Union Unity, Health, Safety and Environment Programme. She is currently Director of the Training and Research Support Centre in Zimbabwe. She has researched and published on issues related to health, economic policy and employment from both an occupational health and public health perspective.

Karen Messing is a Professor of Biology at the University of Quebec at Montreal and a researcher at CINBIOSE (the Centre for the Study of Biological Interactions in Environmental Health). She has published many articles on various aspects of occupational health in jobs occupied by women, and carried out research in partnership with Quebec unions, her most recent book being One Eyed Science: Occupational Health and Women Workers, published by Temple University Press in 1998.

Theo Nichols is Professor of Sociology at the University of Bristol and Editor of the journal Work, Employment and Society. He has written widely in the area of economic sociology. His recent publications include Work and Occupation in Modern Turkey (edited with Erol Kahveci and Nadir Sugur, 1996) and The Sociology of Industrial Injury (1997). 
Sarah Payne lectures in health policy at the School for Policy Studies, University of Bristol. Her research interests include gender and mental health issues in the delivery of mental health services, and inequalities in health and deprivation, particularly in relation to women's experience of poverty and the experience of deprivation in rural areas.

Simon Pickvance has worked as an Occupational Health Advisor in the primary care system in Sheffield since 1980 . He is also a Senior Research Fellow at the Centre for Environmental and Occupational Health Policy at De Montfort University and co-editor of the Workers' Health International Newsletter. Recent publications include contributions to the International Labour Organisation Encyclopedia of Occupational Health and Safety and a handbook on Occupational Health and Safety for Steelworkers.

Ruth Pinder is Associate Research Fellow at the Centre for the Study of Health, Brunel University, and Research Fellow at Queen Mary Westfield College, University of London. She has published widely in the field of chronic illness and disability, including The Management of Chronic Illness: Patients' and Doctors' Perspectives on Parkinson's Disease. She is also an Education Consultant and runs workshops on disability and gender for health care professionals within the British Postgraduate Medical Federation.

Annette Scambler has taught sociology and women's studies for the Open University for 15 years. She has honorary lectureships at University College London and at Imperial College, and she was a Visiting Professor in the Department of Sociology at Emory University, Atlanta, USA, in 1998. She has researched women's health issues, her publications including: (as co-author) Menstrual Disorders (Routledge, 1993) and (as co-editor) Rethinking Prostitution: Purchasing Sex in the 1990s (Routledge, 1997).

Graham Scambler is Reader in Sociology and Director of the Unit of Medical Sociology at University College London. He was a Visiting Professor in the Department of Sociology at Emory University, Atlanta, USA, in 1998. His interests include social theory, health inequalities, chronic and stigmatizing illness, and the sex industry. Recent publications include: (as editor) Sociology as Applied to Medicine (4th edn, Saunders, 1997); (as co-editor) Rethinking Prostitution: Purchasing Sex 
in the 1990s (Routledge, 1997); and (as co-editor) Modernity, Medicine and Health: Medical Sociology Towards 2000 (Routledge, 1998).

Andrew Watterson is Professor of Occupational and Environmental Health and Director of the Centre for Occupational and Environmental Health at De Montfort University, Leicester, where he is also Head of the Department of Health and Continuing Professional Studies. He is a registered safety practitioner, his research interests lying in interdisciplinary approaches to occupational and environmental health, especially lay and worker epidemiology and toxicology. He has published widely in this field, including the second edition of The Role of the Health and Safety Manager (with Les Wright) in 1998.

Tamsin Wilton is Reader in the Sociology of Sex and Sexualities in the School of Health Sciences at the University of the West of England. Her publications include En/Gendering AIDS: Deconstructing Sex, Text and Epidemic; Finger Licking Good: The Ins and Outs of Lesbian Sex; and (edited with Lesley Doyal and Jennie Naidoo) AIDS: Setting a Feminist Agenda. Her textbook on sexuality for health and social care professionals will be published by the Open University Press in 1999. 


\section{PREFACE}

The impetus for this book came from several sources. At one level we were both aware of a number of theoretical and methodological assumptions that have impeded the study of health and work. We also recognised the increasing need for interdisciplinary collaboration in order to align the separate foci of the various contributing disciplines. While specialist literature addresses technical problems within the workplace, it often overloks the social dimensions of risk. Similarly, psychologists have studied the impact of work stress on individuals but have paid less attention to the broader social processes involved in the construction of occupational health and disease. As far as sociology is concerned, research on labour markets and processes is well established but often seems to be founded on the assumption that it is the economic consequences of work that matter. While medical sociologists have examined the socioeconomic determinants of health, and highlighted employment status as a marker of broad social divisions, they have paid relatively little attention to the health effects of work itself.

These problems are compounded by those arising from reliance on limited and outmoded definitions of 'work'. Feminist critiques of this focus on paid employment in the productive sphere are now familiar but they are yet to enter mainstream research and practice in the field of occupational health. Finally, biological reductionism and technological determinism have often rendered occupational health research and practice unable to respond to the increasingly complex, chronic and multicausal nature of work-related ill health.

The problems of serial invisibility are responsible for various forms of epidemiological bias in occupational health research that are addressed in this book. The book aims to introduce interdisciplinary and global perspectives to the study of work and risk in order to inform both theory and practice. It is intended for students of social and health sciences as well as researchers, practitioners and policy makers in all the fields relating to health and work.

It is perhaps ironic that this project arose out of experiences very similar to some of those described in the pages that follow; the lack of 
awareness of many health professionals about occupational health issues; the inadequacy or non-existence of workplace occupational health services; the difficulty of reconciling 'lay' and 'expert' views amd the harmfulness of some well meaning but non-evidence-based clinical interventions. One of us (Norma Daykin) had the misfortune to experience these at first hand, an experience which led her to initiate the discussions between us which led to the idea for the book.

The book also testifies to the possibility of rehabilitation, underpinned in this case by the support and collaboration of colleagues, the availability of appropriate technical support, the reflexivity and skill of some (orthodox and complementary) health practitioners and, not least, the encouragement of students and friends. Special thanks are due to Nick Fox and Tamsin Wilton whose enthusiasm and support helped to relaunch the idea at a critical time and to Lorraine ayensu who never wavered in her belief and encouragement. We are also grateful to colleagues who helped in practical ways, in particular Jenny Dafforn and Julie Packer at the University of the West, both of whom gave invaluable secretarial support. Not least, thanks are due to the staff at Macmillan, in particular Houri Alavi whose efficiency and interest in the project helped sustain it until completion. 


\section{ACKNOWLEDGEMENTS}

The authors and publishers wish to thank the following for permission to use copyright material:

Frank Cass Publishers for Figure 5.9 from Middle Eastern Studies, $31(2)$.

HMSO for Figure 11.1 from A Guide to Risk Management for Environmental Protection, 1995, Crown Copyright.

London Hazard Centre for Table 6.6 from The Asbestos Hazards Handbook, 1995.

Rory O'Neill for Table 6.3 from Asthma at Work, 1995, Hazard Publications.

WHO European Centre for Environment and Health for Tables 6.2 and 6.4 from Concern for Europe's Tomorrow and Health and the Environment in the WHO European Region. Stuttgart, Wissenschaftliche Verlagsgesellschaft, 1995.

Every effort has been made to trace all the copyright holders, but if any have been inadvertently overlooked the publishers will be pleased to make the necessary arrangement at the first opportunity. 